\title{
Perspectives of Development of Luxury Nautical Tourism in the Republic of Croatia
}

\begin{abstract}
:
Nautical Tourism represents one of the most important and significant elements of today's Croatian tourism product. This specific form of tourism experienced significant qualitative changes over the years due to the changes in the preferences of today's yachtsmen, who are still very interested in experiencing natural attractions of the destination they reside in and in spending active holidays. Besides, they are increasingly oriented towards maximum quality and luxury of the tourism offer more than ever and are willing to pay for it significantly. The most recent results indicate that today's yachtsmen show a significantly high level of satisfaction with the Croatian nautical tourism offer. However, in order to be able to satisfy their growing needs, it is necessary to introduce additional improvements of the current tourism offer elements, as well as new elements, with the primary focus on satisfying the need for luxury. The main purpose of this paper is to present the current state of the Croatian Nautical Tourism and the importance of introducing elements of luxury in its offer, all with the goal to provide a greater level of satisfaction for yachtsmen and to position Croatia as a competitive nautical tourist destination within the world's nautical tourism flows.
\end{abstract}

Key words: Nautical tourism, luxury, nautical tourism of Croatia, competitiveness

\section{Introduction}

Over the years tourism has acquired new dimensions, properties and directions in the context of a fast changing world and forces of geographical transformation, globalization and international migration $[7,15]$, which resulted in a development of a new and modern tourism product adjusted to the needs of new tourists. Globalization had a tremendous influence on today's tourism trends, which impose new perceptions of tourism, as well as the emergence of "new" tourists. Today tourists are in search for new and unique experiences, they express an increasing number of needs not only during their stay in a destination, but also during the entire process of travelling to a destination, during which they want a personalized approach. In order to achieve further business success and competitive positioning on the tourism market, the already 
present destination elements need to be enriched by additional activities and destination excellence needs to be measured by tourists' realized expectations and experiences. The diversity of needs and motives is the precise reason why people choose to visit and stay in a particular destination, as well as the reason why a destination is capable of achieving a qualitative shift from the standard tourism offer. The main accent of success must be on the provision of a constant quality of a tourism product [41]. The focus on quality has become one of the key success factors for tourism service providers [13, 187] and has shown a tremendously strong influence on the future development of every single form of tourism offer, one of them being in particular Nautical Tourism. Gračan [20] emphasizes the fact that over the years Nautical Tourism has reached significant proportions of mass migrations, where movements of a significantly large number of people along seashores have become more expressed from year to year. Tourists are becoming more and more oriented towards using seawater, not just for the traditional tourism offer of Bathing tourism but rather for spending their time sailing in the open sea, recreating, and enjoying various forms of water sports with the goal of having an active rest away from the daily routine.

When considering Nautical Tourism and all the characteristics of its offer, the term quality automatically comes to mind. The reason is that contemporary boaters possess high purchasing power, they are willing to spend significant amounts of their hard-earned funds during their holidays and are constantly in search of experiencing luxury and achieving the appropriate value and experience for money.

Croatia started developing Nautical Tourism very late; the beginning of its development was registered in the 1960's. For a considerable period, the development of Nautical Tourism in Croatia had not been supported by the appropriate social politics and no significance had been given to the planning of its development $[20,196]$. However, this has changed over the years, and Croatia is registering positive movements in terms of quality of the Nautical Tourism offer. Yet, the question is, considering the current level of development of the Nautical Tourism offer, whether Croatia is capable of providing quality to the point that it could be considered luxurious. The purpose of this paper is to present the importance of luxury as an integral part of the Nautical tourism offer, while the goal is to present the need for further improvement of the Nautical tourism offer in Croatia through the inclusion of luxury elements. The paper is structured as follows: after the introduction and within the first chapter titled Basic Characteristics of Luxury Tourism and its Significance as a part of a Contemporary Tourism Offer the author provides theoretical insights into the importance of luxury as a part of a modern tourism product. The second chapter, titled Nautical Tourism Offer of the Republic of Croatia -Presentation of the Current State reflects the newest insights into the present situation, as well as the profile of today's yachtsmen. Within the third chapter titled What are the Potentials for Developing Luxury Nautical Tourism in Croatia? Proposition of Developmental Guidelines, the author provides, based on the results from the second chapter, suggestions on how to improve the current Croatian nautical tourism product. Finally, there follow conclusion remarks. 


\section{Basic Characteristics of Luxury Tourism and its Significance as Part of the Contemporary Tourism Offer}

The world tourism continues recording a strong growing trend year after year, as witnessed by the United Nations World Tourism Organization [40] that tracks the trend movements. The most recent publication from 2018 states that in 2017 international tourist arrivals registered the total of 1.326 million, an increase of approximately 86 million in relation to the year 2016. Europe continued to lead with its share of high $51 \%$, followed by Asia and the Pacific (24\%), Americas (16\%), Africa (5\%) and Middle East (4\%). Receipts are also registering growth, respectively in 2017 world tourism registered approximately 1.340 billion of American Dollars, within which Europe again continues leading (519 million), followed by Asia and the Pacific (390 billion), Americas (326 billion), Middle East (68 billion) and Africa (37 billion). Within the continuously growing industry, luxury tourism shows a growing trend $[36,90]$ that is confirmed by the data from the report Shaping the Future of Luxury Travel Future Traveller Tribes 2030 [2]. The projections within this report state that in the future it is expected that the growth rate of outbound luxury trips in the following ten year period will experience an increase of $6.2 \%$, which exceeds by one third the projections for the overall travels $(+4.8 \%)$. The following chart presents the expectations of future growth of luxury travels by the distance.

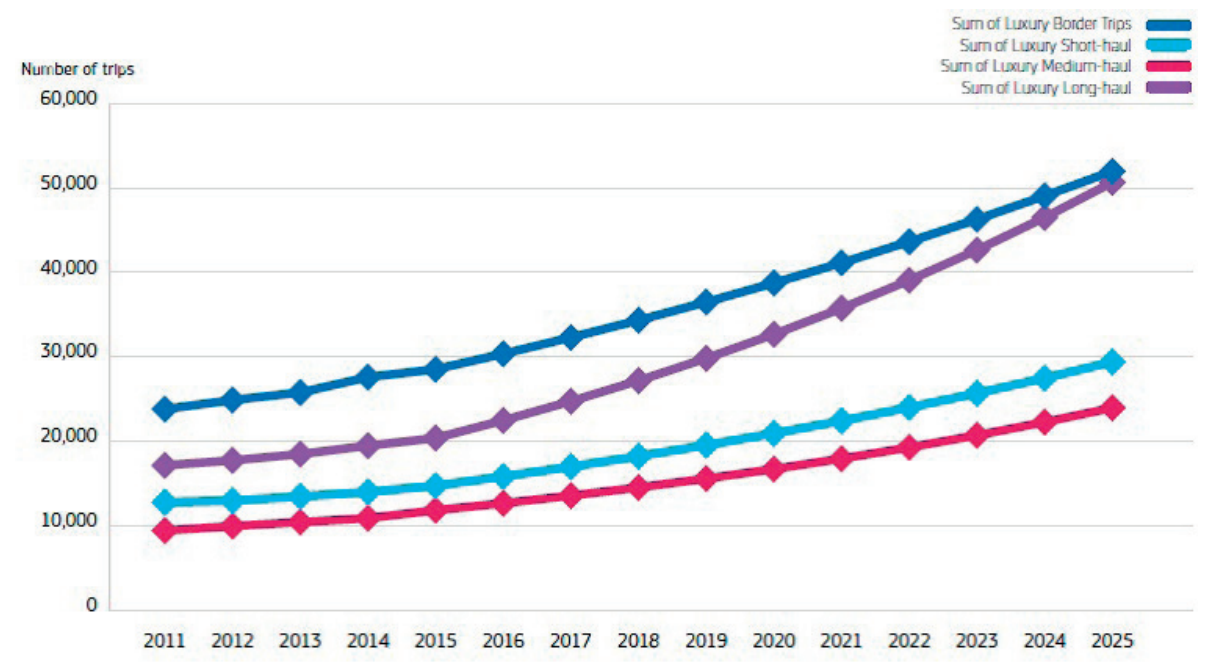

Figure 1 - Growth of luxury travel trips by the distance [2] 
According to the data presented in the preceding chart the luxury border and long haul travels are expected to have the highest growth, followed by luxury short and medium haul travels. Northern America and Western Europe are currently accounting for $64 \%$ of the world's outbound luxury travels despite the fact that they make only $18 \%$ of the entire world population. As for Asia and the Pacific, it is expected that there will be a faster overall growth than in Europe, of 7.1\% in the period 20112025. However, a deceleration is expected there in the period 2015-2025, unlike in the European region where a steady growth of $6.3 \%$ up by 2015 is expected to continue [2]. These encouraging figures clearly emphasize the need for further investments in the development of tourism product of many destinations. However, in order to be able to reach that high level of development of the tourism product, it was (and still is) necessary to truly understand what is to be considered luxurious in tourism, in which regard there have been many researches carried out so far.

The term Luxury refers to everything that is possible to obtain that is different, unique and exclusive. Luxury products do not respond to the tourist demand, they are not aimed at satisfying the need of the masses, however, these products and services are offered to everybody, but not everybody can use them due to their purchasing power and high prices these products and services are offered at. In the tourism industry, luxury has taken a form that places a strong emphasis on the value rather than the price, and it is tourists' overall experience in a destination that the value of a tourism product or a service is measured by [27]. Luxury has become the topic of many researches in the contemporary society $[3,37,42$, etc.], but the highest attention has been given to it in the tourism industry, the most developed part of the world economy $[4,6,24,25,28,36,39$, 43, etc.], what is justifiable considering that no tourist destination can competitively position itself on the tourist market without having luxury within its tourism product.

Within today's tourism flows, Europe is most definitely the key market for luxury tourism, especially due to the fact that Europeans tend more and more toward giving preference for new and unique experiences over material possessions, which is a strong stimulus for further development of the luxury tourism market [5]. All this places a difficult task before many destinations that are trying to maintain their current or achieve even greater competitive position on the tourism market. All destinations need to determine what elements of their tourism product are most desirable and for what kind of tourists, and focus their activities towards further development of their tourism offer in order to attract tourists and satisfy their needs. Despite the fact that the Croatian tourism product has been still based mostly on classical Bathing tourism offer, other specific forms of tourism are recording significant growth, one of them being Nautical Tourism. In the following chapter the author analyzes the current state of the Nautical Tourism offer and tries to determine whether Croatia possesses all the necessary pre-conditions for the development of the luxury Nautical tourism offer. 


\section{Nautical Tourism Offer of the Republic of Croatia - Presentation of the Current State}

The Republic of Croatia is situated along the north coasts of the Adriatic Sea. The surface of its mainland amounts 56.542 square miles, and the surface of the territorial sea 31.067 square miles. Croatia is a maritime country with a long history and tradition of maritime industry and tourism. The main natural resource for the development of Nautical Tourism is the Adriatic Sea with an indented coastline $6.176 \mathrm{~km}$ long, of which $4.398 \mathrm{~km}$ belong to the coastline of its 1.244 islands, islets and rocks, with 50 of islands being inhabited. For many years now Croatia has been intensely developing Nautical Tourism. There are two groups of factors that have the most significant share in building the competitiveness of Nautical Tourism: 1.) general factors: climate conditions, attractiveness and cleanliness of the sea, attractiveness of the landscape owing to the richly indented coast and islands including settlements; 2.) special factors: traffic infrastructure availability to the nautical tourism port of departure in relation to the main markets, personal safety and safety of sailing, the number, special distribution and equipment of nautical tourism ports, mooring capacities for vessels in nautical tourism ports or at designated places within public ports, hospitable and qualified personnel, availability of other facilities necessary for the maintenance and equipment of vessels, attractiveness of facilities on the mainland, cultural offer as an important factor of tourism, and nautical services at competitive prices, regulations connected with vessels' sailing and stationing, and taxes [34, 7-8]. According to the Croatian Tourism Development Strategy until 2020, [14], Nautical Tourism (yachting/ cruising) is among the dominant products of the Croatian tourism. Due to its geotraffic situation and one of the most indented coasts in the world, pleasant climate and suitable winds, Croatia is today one of the most desirable nautical destinations in the world. This has been proven by the achieved business results in Nautical Tourism over the years and particularly in the prolonged tourist season, what is of significant importance in a view of the fact that Croatian tourism is still, despite positive movements, marked with seasonality.

Nautical Tourism represents a specific form of contemporary tourist movements as well as one of the most expanded forms of tourist recreation. Over the years, man has managed to overcome natural obstacles in the sea with the help of science and technology developed within the maritime industry, what has provided a solid basis for the development of Nautical Tourism. This specific form of tourism managed to attract significant attention at the global level and it is justly considered to be one of the priceless segments within the entire family of tourism. This specific form of tourism is indispensable for the Croatian tourism offer that is based on the advantages brought forward by its successful development [20, 185], which is why it has become one of the most important research topics in Croatia from various points of view. Over the years significant emphasis was given to the development of new theories and 
definitions of Nautical Tourism $[31,32,33]$ and how this specific form of tourism is important for the economic development of Croatia as a tourist destination [29, 30]. Favro's work is oriented towards the analysis of natural resources as a precondition for the development of Nautical Tourism offer [9, 10], importance and formation of international standards in the development of Nautical Tourism [11], sustainable yachting [8], effects of construction of Nautical Tourism ports [i.e. 12], etc. Gračan is focused on rethinking Nautical Tourism from many different aspects as well, mostly on its importance as a part of the strategic development of the Croatian (nautical) tourism product and its repositioning on the world tourism market [16, 17, 18, 23], its ecological aspects and its development within the Mediterranean tourism flows $[15,21,22]$, how Nautical Tourism can contribute towards branding the Croatian nautical tourism offer, and Croatia as a tourist destination [19], and many others. Today Nautical Tourism represents one of the most important elements of the Croatian tourism offer, with the biggest potential of contributing towards achieving Croatia's even greater competitive positioning on the tourism market. The main goal needs to be further development of a unique and recognizable tourism product that will contribute towards better formation of the identity of Croatia as a nautical destination, with the tourism offer based on preserved natural resources and a long-time rich tourism tradition. In addition, the destination must strive towards profiling itself as a destination of high quality and excellence that will be able to provide luxury services for yachtsmen and enable them to achieve value for money [1]. In order to be able to rethink new ways of the nautical tourism offer development, the primary task must be to determine the current state of development of Nautical Tourism using appropriate quantitative and qualitative indicators. The following table presents the number of vessels permanently moored in ports of Nautical Tourism by the vessel's flag in the period 2014-2018.

The data indicate that in 2018 the total number of vessels in Croatia decreased by $1.28 \%$. However, according to vessels' nationality, the highest increase rate was registered for vessels from France (124.66\%), Poland (76.67\%), Finland (71.43\%), Slovakia (32.90\%), Netherlands (29.50\%), Belgium (28.30\%), Czech Republic $(27.40 \%)$, Norway $(21.40 \%)$, other European countries $(12.88 \%)$, other nonEuropean countries $(8.51 \%)$ and Croatia $(4.34 \%)$. All the other countries recorded a decrease (Austria, Italy, Israel, Germany, Russia, USA, Sweden, Switzerland and United Kingdom). 
Table 1 - Vessels mooring on a permanent basis in ports of Nautical Tourism by the vessel's flag in the period 2014-2018

\begin{tabular}{|c|c|c|c|c|c|c|}
\hline & 2014 & 2015 & 2016 & 2017 & 2018 & $2018 / 2014$ \\
\hline Total & 13.793 & 13.399 & 13.422 & 13.433 & 13.617 & 98.72 \\
\hline $\begin{array}{l}\text { Vessels using only } \\
\text { sea moorings }\end{array}$ & 11.664 & 11.487 & 11.756 & 11.641 & 11.742 & 100.67 \\
\hline $\begin{array}{l}\text { Vessels using only } \\
\text { mainland moorings }\end{array}$ & 2.129 & 1.912 & 1.666 & 1.792 & 1.875 & 88.07 \\
\hline Austria & 1.993 & 1.904 & 1.977 & 1.917 & 1.851 & 92.87 \\
\hline Belgium & 53 & 69 & 75 & 82 & 68 & 128.30 \\
\hline Czech Republic & 135 & 130 & 139 & 146 & 172 & 127.40 \\
\hline Finland & 7 & 7 & 11 & 11 & 12 & 171.43 \\
\hline France & 73 & 90 & 100 & 138 & 164 & 224.66 \\
\hline Greece & 1 & 1 & 2 & 2 & 1 & 100.00 \\
\hline Croatia & 4.957 & 5.013 & 5.039 & 4.944 & 5.172 & 104.34 \\
\hline Italy & 635 & 601 & 591 & 545 & 496 & 78.11 \\
\hline Israel & 4 & 3 & 2 & 1 & 1 & 25.00 \\
\hline Hungary & 129 & 129 & 113 & 112 & 130 & 100.77 \\
\hline Netherlands & 139 & 132 & 138 & 173 & 180 & 129.50 \\
\hline Norway & 23 & 25 & 21 & 25 & 28 & 121.74 \\
\hline Germany & 1.840 & 1.748 & 1.863 & 1.858 & 1.781 & 96.79 \\
\hline Poland & 90 & 104 & 101 & 119 & 159 & 176.67 \\
\hline Russia & 11 & 6 & 7 & 6 & 4 & 36.36 \\
\hline USA & 193 & 147 & 131 & 117 & 95 & 49.22 \\
\hline Slovakia & 155 & 152 & 154 & 153 & 206 & 132.90 \\
\hline Slovenia & 598 & 601 & 575 & 578 & 599 & 100.17 \\
\hline Sweden & 40 & 40 & 47 & 43 & 38 & 95.00 \\
\hline Switzerland & 81 & 69 & 80 & 77 & 73 & 90.12 \\
\hline United Kingdom & 281 & 268 & 302 & 304 & 261 & 92.88 \\
\hline $\begin{array}{l}\text { Other European } \\
\text { countries }\end{array}$ & 132 & 135 & 139 & 153 & 149 & 112.88 \\
\hline $\begin{array}{l}\text { Other non-European } \\
\text { countries }\end{array}$ & 94 & 113 & 149 & 137 & 102 & 108.51 \\
\hline
\end{tabular}

Source: Author according to [38] 
Table 2: Achieved income of Nautical Tourism ports in the period 2014-2018 in thousands of HRK (without VAT)

\begin{tabular}{|l|c|c|c|c|c|c|}
\hline & 2014 & 2015 & 2016 & 2017 & 2018 & $2018 / 2014$ \\
\hline Republic of Croatia & 716.555 & 753.412 & 768.938 & 855.166 & 856.550 & 119.54 \\
\hline Mooring rents & 527.811 & 519.360 & 539.210 & 598.191 & 618.150 & 117.11 \\
\hline Permanent moorings & 424.090 & 416.154 & 422.755 & 469.601 & 483.553 & 114.02 \\
\hline Transit moorings & 103.721 & 103.206 & 116.455 & 128.590 & 134.597 & 129.77 \\
\hline Repair services & 48.340 & 57.185 & 60.202 & 65.862 & 69.761 & 144.31 \\
\hline Other incomes & 140.404 & 176.867 & 169.511 & 191.113 & 168.639 & 120.11 \\
\hline
\end{tabular}

Source: Author according to [38]

It is evident that in the period 2014-2018 total income of Nautical Tourism ports reached a $19.54 \%$ increase, of which the major portion came from repair services $(+44.31 \%)$, transit $(+29.77 \%)$, other incomes $(20.11 \%)$, and mooring rents $(17.11 \%)$ of which $29.77 \%$ from transit moorings, and $14.02 \%$ from permanent moorings.

In order to obtain a clearer picture of current attitudes of yachtsmen concerning the current Nautical Tourism offer of the Republic of Croatia, the author will present the most recent findings of Attitudes and Consumption of Yachtsmen in Croatia TOMAS Nautica 2018 published by the Institute for Tourism Zagreb in the Republic of Croatia. According to the age, the majority of yachtsmen belonged to the age group $36-45$ (29.4\%), followed by 46-55 (25.8\%), 26-35 (21.1\%), 56+ (16.6\%), and up to $25(7.1 \%)$. The majority of them is highly educated, with university degree or higher (50.6\%), 36.3\% college ( 2 or 3 years) degree, and $13.1 \%$ secondary education or lower. They possess a high buying power, respectively $26.9 \%$ of them have monthly income of 3.501-5.000€, followed by the yachtsmen with monthly income of 3.001$3.500 €(17.3 \%), 5.001-7.500 €(13.7 \%), 2.501-3.000 €(9.7 \%), 7.501-10.000 €(8 \%)$, $10.001+€(7.3 \%), 2.001-2.500 €(6.4 \%), 1.501-2.000 €(4.8 \%), 1.001-1.500 €(3.5 \%)$ and up to $1000 €(2.5 \%)$. They are very loyal to Croatia as a nautical destination, $27.1 \%$ of them visited Croatia 6 times or more, followed by $3-5$ visits (23.2\%), 2 visits (18.2\%), while $31.5 \%$ visited Croatia for the first time. Internet is still the most used source of gathering information about the Croatian Nautical tourism offer (38.4\%), as well as experiences during the previous stay $(31.1 \%)$, and recommendation of friends and family $(23.7 \%)$, while for $17.5 \%$ no information were necessary. The majority prefer to stay in Croatian nautical destinations 4-7 days (59.4\%), followed by 8-14 days $(26.3 \%), 15-21$ day $(7.7 \%), 22+$ days $(4.6 \%)$, and only $2 \%$ prefer to stay for only 1-3 days. According to the number of visited marinas during the sailing, $27.8 \%$ prefer to visit one marina, $26.5 \%$ two marinas, $24.8 \%$ four and more marinas, and $20.9 \%$ three marinas [26, 31-37]. 
Table 3: Activities of yachtsmen during their stay in the Republic of Croatia

\begin{tabular}{|l|c|}
\hline Activities & $\%$ \\
\hline Visiting restaurants & 95.9 \\
\hline Shopping & 84.2 \\
\hline Visiting pasty shops, coffee shops, etc. & 53.2 \\
\hline Scuba diving & 47.9 \\
\hline Walking in nature (hiking) & 40.2 \\
\hline Fishing & 33.8 \\
\hline Visiting national parks/protected natural areas & 33.0 \\
\hline Visiting the sights, museums and exhibitions & 32.1 \\
\hline Other sports activities in the sea (beside swimming and bathing) & 30.6 \\
\hline Visiting local parties & 29.9 \\
\hline Dance or disco & 20.2 \\
\hline Sports activities on the land & 15.8 \\
\hline Visiting concerts, theatre, and manifestations & 14.6 \\
\hline Visiting theme/water parks & 11.0 \\
\hline Visiting wine and oil roads & 8.7 \\
\hline
\end{tabular}

Source: Author according to [26]

It is visible from the above table that during their stay in a marina or a port yachtsmen tend to be very active as guests, considering that a significant percentage of them (96\%) tend to explore the gastronomic and oenological offer, and they are very much interested in shopping (84\%). Other activities they are interested in are visiting pasty shops, coffee shops, etc. (53.2\%), Scuba diving (47.9\%), Walking in nature (hiking) (40.2\%), Fishing (33.8\%), Visiting national parks/protected natural areas $(33.0 \%)$, Visiting the sights, museums and exhibitions (32.1\%), other sports activities in the sea (beside swimming and bathing) (30.6\%), etc. 
Table 4: Evaluation of the level of tourists' satisfaction with the elements of the Nautical Tourism offer in the Republic of Croatia

\begin{tabular}{|l|c|}
\hline Elements & Level \\
\hline Nature and landscape attractiveness & Very high \\
\hline Personal safety & Very high \\
\hline State of the boat (correctness, tidiness, equipment, etc.) & Very high \\
\hline Staff service in marinas & Very high \\
\hline Acceptance in the marina** & Very high \\
\hline Richness of gastronomic offer in the destinations & Very high \\
\hline Traffic availability to the starting port & Very high \\
\hline Spatial layout of the marinas & Very high \\
\hline Water supply (cold and warm) in marinas & Very high \\
\hline Accessibility of water and electricity connections in marinas & Very high \\
\hline Ecological preservation & Very high \\
\hline $\begin{array}{l}\text { Availability of information in marinas about the tourism offer of } \\
\text { the destination }\end{array}$ & Very high \\
\hline Reception at the airport ** & Very high \\
\hline Total offer for yachtsmen & Very high \\
\hline Arrangement and cleanliness of the environment in marinas & Very high \\
\hline Moorings (width, correctness) & Very high \\
\hline Quality of technical repair service (speed of repairs) in marinas & Very high \\
\hline "Value for money" of total offer for yachtsmen & High \\
\hline Diversity of cultural manifestations & High \\
\hline Quality of restaurant services in marinas & High \\
\hline Diversity of entertainment facilities & High \\
\hline Sanitary facilities in marinas & High \\
\hline Richness of sports facilities in the destinations & High \\
\hline Possibility of shopping in marinas & High \\
\hline
\end{tabular}

Source: Author according to [26]

** Only for yachtsmen in Croatian charter

The preceding table presents the yachtsmen's level of satisfaction with the nautical tourism offer in 2017. Yachtsmen show a very high level of satisfaction with the significantly high number of elements of nautical tourism offer, like the sense of personal safety, staff service in marinas, richness of gastronomic offer, ecological 
preservation, ability to obtain the necessary information in marinas about the tourist destination, total offer for yachtsmen, quality of technical repair services, etc. Value for money for yachtsmen, quality of restaurant services in marinas, diversity of entertainment facilities, possibility of shopping in marinas, etc. were graded slightly lower, as High.

Table 5: Yachtsmen's average daily consumption on their voyage/sailing in EURO according to the vessel ownership in the Republic of Croatia [26]

\begin{tabular}{|l|c|}
\hline $\begin{array}{l}\text { Yachtsmen's average daily expenditure on their voyage/sailing } \\
\text { according to the vessel ownership }\end{array}$ & $(€)$ \\
\hline Total & 126.18 \\
\hline Boat expenditures & 87.60 \\
\hline Expenditures for renting vessels & 46.53 \\
\hline Expenditures for a skipper (unless they are not included in the lease) & 4.70 \\
\hline $\begin{array}{l}\text { Expenditures for renting moorings (not including the expenditures for } \\
\text { permanent mooring) }\end{array}$ & 11.90 \\
\hline Expenditure for the fuel & 20.97 \\
\hline Expenditure for the repair service and other expenditures & 3.51 \\
\hline Other expenses during the sailing & 38.58 \\
\hline Accommodation on the mainland & 1.38 \\
\hline Restaurant services & 19.40 \\
\hline Shopping & 12.58 \\
\hline Culture, entertainment, sports, recreation and one-day trips & 3.78 \\
\hline Other & 1.44 \\
\hline
\end{tabular}

Source: Author according to [26]

** Only for yachtsmen in Croatian charter

In 2017 the average daily consumption amounted 126.18 EUR of which the major portion was related to the expenses related to the boat: renting vessels, fuel, and skipper (if not included in the price), etc. The other expenses amounted to 38.58 EUR per day, of which 19.40 EUR was spent on restaurant services, 12.58 EUR on shopping, 3.78 EUR on cultural, entertainment, sports recreational and one-day trip activities, etc.

Within this chapter the author presented the current state of the Nautical Tourism offer of the Republic of Croatia. Previously presented quantitative indicators of the number of permanently moored vessels in Nautical Tourism ports by the flag are unsatisfactory, considering that a decrease was registered at the state level, as 
well as from some of the countries with a high buying power such as Austria, Italy, Russia, Germany, Switzerland, etc. As far as qualitative indicators are concerned presenting the level of satisfaction and consumption, the situation is rather different, considering that the yachtsmen expressed mostly a very high level of satisfaction with the elements of nautical tourism offer, as results evident from the registered nautical tourist consumption. However, further actions are necessary to improve the elements for which the yachtsmen expressed a high level of satisfaction (i.e. Value for money of total offer for the yachtsmen, quality of restaurant services in marinas, diversity of entertainment facilities, possibility of shopping in marinas, etc.). Improvement of these elements of nautical tourism offer is of extreme importance considering that without being able to offer total quality to the visiting yachtsmen, it is impossible to profile itself as a luxury nautical tourist destination and compete with the competitive destinations on the tourism market.

\section{What are the Potentials of Developing Luxury Nautical Tourism in Croatia? Proposition of Developmental Guidelines}

Over the years, Croatian Nautical Tourism has recorded growth in terms of qualitative improvements as visible from the most recently published results of Attitudes and Consumption of Yachtsmen in Croatia TOMAS Nautica 2018 presented in the preceding chapter. The results indicate that Croatia is not developing its nautical tourism product solely on the basis of natural attractiveness (indented coastline, islands, attractive landscape, clear blue sea, climate, etc.), but it has been improving the quality and diversity of its tourism offer. However, additional improvements are still necessary in order for Croatia to be able to position itself on the tourism market as a luxury nautical destination.

It is advisable to conduct the following activities $[1,35]$ :

- To define a very clear luxury nautical offer based on total quality (it is advisable to monitor and implement the best practices of the competing nautical tourist destinations);

- Yachtsmen have shown a high level of interest in exploring gastronomic offer. The level of satisfaction with the gastronomic offer in the destination was marked as very high, unlike the level of satisfaction with the gastronomic offer in marinas that was graded a bit lower, i.e. as high. It is advisable to maintain the current activities, yet aiming at the same time towards additional improvements of restaurant services (in marinas in particular). Particular attention needs to be aimed towards introducing in luxury restaurants a carefully developed gastronomic and oenological offer according to the world's trends of good practice, while at the same time preserving Croatian authenticity as one of the most important stimuli for visiting Croatia;

- Introduction of casinos as a part of a tourism product; 
- Building indoor and outdoor swimming pools;

- Stronger introduction and development of cultural manifestations which would reflect the tradition of the destination in which the yachtsmen are currently residing;

- Improvement of the offer of sports facilities;

- Improvement of possibilities for shopping in marinas (foreign and domestic branded products, domestic authentic souvenirs, etc.). Shopping was ranked as the second activity for which yachtsmen show significant interest during their stay in a marina or a nautical port, but the level of satisfaction was marked as high, which clearly points to the possibility of further improvements;

- The price of the nautical tourism product must be completely harmonized with the quality of a nautical tourism product and adapted to the targeted market niche;

- Determine the way of distribution of a tourism product (direct or indirect);

- Form a unique and recognizable nautical tourism brand;

- Undertake appropriate marketing activities aimed at successful promotion of the luxury nautical tourism offer on the tourism market and constantly monitor the success of marketing activities.

Implementation of presented activities will enable tourism offer developers to additionally improve the current Nautical tourism offer and bring it to the level of luxury which will attract a higher number of yachtsmen with high purchasing power (especially from the countries that recorded a decrease of visiting vessels in the last four years). It is justifiably expected that this would have a positive influence on the growth of yachtsmen's consumption and competitiveness of the tourism offer, since they would be able to achieve their value and experience for money, and recommend Croatia as a luxury nautical destination definitely worth the visit.

\section{Conclusion}

In this paper the author presented the key characteristics of the current state of the Nautical Tourism offer of Croatia, as well as the importance of luxury as a feature of a (nautical) tourism product. This specific form of tourism is recognized as one of the most significant parts of Croatian tourism, as witnessed by the fact that tourism offer developers are continuously working on the improvement of its quality and diversity that in the end resulted in tourists not only returning multiple times, but also expressing mostly a very high level of satisfaction with the elements of nautical tourism offer. Croatia is observing current trends on the nautical tourism market and is making efforts to implement good practices taken from the competing destinations. However, in order to be able to achieve its maximum success, it is mandatory for Croatia to undertake further previously proposed actions of development of the nautical tourism product that will be based on luxury, and will thus enable the return of the previous 
yachtsmen with high purchasing power from the countries that registered a decrease in the number of visiting vessels, attracting new tourists who still haven't visited Croatia, and finally positioning Croatia on the European and world tourism market as a destination of high quality and excellence.

\section{Literature}

1. Alkier R., Drpić, D. \& Milojica, V. (2015) Doprinos marketinških strategija u ostvarenju konkurentne ponude nautičkog turizma Republike Hrvatske. Pomorski zbornik. 49-50 (1), 181205. Available from https://hrcak.srce.hr/index.php?show=clanak\&id_clanak_jezik=203744 [Accessed 5 $5^{\text {th }}$ April 2019]

2. Amadeus Airports. (2016) Shaping the Future of Luxury Travel Future Traveller Tribes 2030. Available from https://amadeus.com/documents/en/travel-industry/report/shaping-the-future-ofluxury-travel-future-traveller-tribes-2030.pdf [Accessed $5^{\text {th }}$ April 2019]

3. Atwal, G. \& Williams, A. (2009) Luxury Brand Marketing-The experience is everything!. Journal of Brand Management. 16 (5-6), 338-346. Available from https://link.springer.com/ article $/ 10.1057 / \mathrm{bm} .2008 .48$ [Accessed $5^{\text {th }}$ April 2019]

4. Barron, P. \& Greenwod, A.B. (2006) Issues Determining the Development of Cruise Itineraries: a Focus on the Luxury Market. Tourism in Marine Environments. 3 (2), 89-99. Available from https://www.ingentaconnect.com/content/cog/tme/2006/00000003/00000002/art00003;jsessioni $\mathrm{d}=2$ f8uo24jlgd6u.x-ic-live-02 [Accessed $5^{\text {th }}$ April 2019]

5. CBI Ministry of Foreign Affairs. (2018) What are the opportunities for luxury tourism from Europe?. Available from https://www.cbi.eu/market-information/tourism/luxury-tourism [Accessed 5 ${ }^{\text {th }}$ April 2019]

6. Correia, A., Kozak, M. \& Kim, S.S. (2017) Luxury shopping orientations of mainland Chinese tourists in Hong Kong: Their shopping destination. Tourism Economics. 24 (1), 92-108. Available from https://journals.sagepub.com/doi/abs/10.1177/1354816617725453 [Accessed $5^{\text {th }}$ April 2019]

7. Dujmović, M. \& Vitasović, A. (2013) Changing World of Tourism. In: Denisa Krbec (ed.). Changing World of Tourism. Sustainable Tourism: An Interdisciplinary Approach. Pula, University of Juraj Dobrila in Pula, pp. 15-27

8. Favro S., Gržetić, Z. \& Kovačić, M. (2010) Towards sustainable yachting in Croatian traditional island ports. Environmental Engineering and Management Journal. 9 (6), 787-795. Available from http://eemj.eu/index.php/EEMJ/article/view/2742 [Accessed $5^{\text {th }}$ April 2019]

9. Favro, S. \& Saganić, I. (2007) Prirodna obilježja hrvatskog litoralnog prostora kao komparativna prednost za razvoj nautičkog turizma. Geoadria. 12 (1), 59-81. Available from https://hrcak.srce. $\mathrm{hr} / 21859$ [Accessed $5^{\text {th }}$ April 2019]

10. Favro, S., Gržetić, Z. \& Fredotović Božić, K. (2010) Untouched nature: challenge to nautical tourism sustainable development. In: Selikhovkin, A. (ed.) Proceedings of Ecological tourism: trends and perspectives of development in the global world, 15-16 April 2010, Saint Petersburg, Russia. Saint Petersburg. pp. 37-42

11. Favro, S., Kovačić, M. \& Gržetić, Z. (2009) Significance and Role of International Standards in Development of Croatian Nautical Tourism. Promet - Traffic \& Transportation. 21 (3), 167174. Available from https://hrcak.srce.hr/index.php?show=clanak\&id_clanak_jezik=122127 [Accessed $5^{\text {th }}$ April 2019]

12. Favro, S., Kovačić, M. \& Gržetić, Z. (2009) Socio-cultural effects and consequences of construction of nautical tourism ports: Case study: Croatia. In: Vičić, S. (ed.) IV Biennial International Congress Hotelplan 2009: Hospitality and Tourism-Holistic Approach, 22-23 April 2009, Belgrade, Serbia. Belgrade: College for Hotel Management. pp. 569-577 
13. Foris, D., Popescu, M. \& Foris, T. (2017) A Comprehensive Review of the Quality Approach in Tourism. In: Butowski, L. (ed.). Mobilities, Tourism and Travel Behavior-Contexts and Boundaries. Poland, Lodz University of Technology, pp. 159-188

14. Government of the Republic of Croatia. (2013) Strategy of Development of Tourism of the Republic of Croatia until 2020. Available from https://mint.gov.hr/UserDocsImages//arhiva// Strategija-turizam-2020-editfinal.pdf [Accessed 5 ${ }^{\text {th }}$ April 2019]

15. Gračan, D. \& Alkier Radnić, R. (2005) Ekološki aspekti razvoja nautičkog turizma europskog dijela Mediterana. Pomorski zbornik. 43 (1), 219-239. Available from https://hrcak.srce.hr/index. php?show=clanak\&id_clanak jezik=79648 [Accessed $5^{\text {th }}$ April 2019]

16. Gračan, D. (2004) Značaj i uloga nautičkog turizma u strategiji razvoja turizma Opatijske Rivijere. Tourism and hospitality management. 10 (2), 151-156. Available from https://hrcak. srce.hr/index.php?show=clanak\&id_clanak_jezik=267968 [Accessed $5^{\text {th }}$ April 2019]

17. Gračan, D. (2005) Uloga nautičkog turizma u repozicioniranju turizma istarske županije. Tourism and hospitality management. 11 (2), 147-154. Available from https://hrcak.srce.hr/ index.php?show $=$ clanak\&id_clanak_jezik $=267257$ [Accessed $5^{\text {th }}$ April 2019]

18. Gračan, D. (2006) Strateško promišljanje razvoja nautičkog turizma u Hrvatskoj. Tourism and hospitality management. 12 (1), 111-117. Available from https://hrcak.srce.hr/index. php?show=clanak\&id_clanak_jezik=92892 [Accessed $5^{\text {th }}$ April 2019]

19. Gračan, D., Alkier Radnić, R. \& Krstinić Nižić, M. (2009) Nautical Tourism as the Means of Branding the North-Adriatic Destinations in Tourism Market. In: Albers, A. \& Myles, P.B. (eds.) The 6th International Congress on Coastal and Marine Tourism The Spirit of Ubuntu, Connecting Continents, Places and People, 23 June 2009, Elizabeth-Nelson Mandela Bay, South Africa. Elizabeth-Nelson Mandela Bay: Kyle Business Projects. pp. 273-284

20. Gračan, D., Alkier Radnić, R. \& Uran, M. (2009) Strateška usmjerenja nautičkog turizma u Europskoj Uniji, Opatija, Faculty of Tourism and Hospitality Management in Opatija

21. Gračan, D., Alkier Radnić, R. \& Vizjak, A. (2006) Razvoj nautičkog turizma na Mediteranu. Pomorski zbornik. 44 (1), 123-137. Available from https://hrcak.srce.hr/index. php?show $=$ clanak\&id_clanak_jezik=79691 [Accessed $5^{\text {th }}$ April 2019]

22. Gračan, D., Alkier Radnić, R. \& Vizjak, A. (2007) The Participation of Croatian Nautical Tourism in Nautical Tourism Flows in the Mediterranean. In: Proceedings of IX International Conference Strategic Development of Tourism Industry in the 21 $1^{\text {st }}$ Century, 25-26 May 2007, Ohrid, Macedonia. Ohrid: Faculty of Tourism and Hospitality. pp. 1-11

23. Gračan, D., Gregorić, M. \& Martinić, T. (2016) Nautical tourism in Croatia: current situation and outlook. In: Maškarin Ribarić, H. \& Smolčić Jurdana, D. (eds.) $23^{\text {rd International Congress }}$ Tourism and Hospitality Industry 2016 Trends and Challenges, THI 2016, $28-29$ April 2016, Opatija. Opatija: Faculty of Tourism and Hospitality Management in Opatija. pp. 66-79

24. Han, H. \& Hyun, S.S. (2018) Role of motivations for luxury cruise traveling, satisfaction, and involvement in building traveler loyalty. International Journal of Hospitality Management. 70, 75-84. Available from https://www.sciencedirect.com/science/article/pii/S0278431917305182 [Accessed 5 $5^{\text {th }}$ April 2019]

25. Hyun, S-S. \& Han, H. (2015) Luxury Cruise Travelers: Other Customer Perceptions. Journal of Travel Research. 54 (1), 107-121. Available from https://journals.sagepub.com/doi/ abs $/ 10.1177 / 0047287513513165$ ? journalCode $=j$ trb [Accessed $5^{\text {th }}$ April 2019]

26. Institute for Tourism. (2018) Attitudes and consumption of Yachtsmen in Croatia TOMAS Nautica 2018. Available from http://www.iztzg.hr/hr/institut/tomas-nautika/ [Accessed $5^{\text {th }}$ April 2019]

27. Interface Tourism Space. (2019) What luxury tourism means. Available from http:// interfacetourism.es/en/2017/01/31/what-luxury-tourism-means/ [Accessed $5^{\text {th }}$ April 2019]

28. Koch, K-D. (2009) Luxury Tourism-Insights into an Underserved Market Segment. In: Conrady, R. \& Buck, M. (eds.). Trends and Issues in Global Tourism 2009. Berlin, Springer Verlag Berlin Heidelberg, pp. 183-191 
29. Kovačić, M. \& Favro, S. (2012) Mogućnosti razvoja nautičkog turizma na području zadarske županije. Pomorstvo: journal of maritime studies. 26 (1), 151-164. Available from https://hrcak. srce.hr/index.php?show $=$ clanak\&id_clanak jezik $=124282$ [Accessed $5^{\text {th }}$ April 2019]

30. Kovačić, M., Gržetić, Z. \& Bošković, D. (2011) Nautical Tourism in Fostering the Sustainable Development: A Case Study of Croatia's Coast and Island. Tourismos: an International Multidisciplinary Journal of Tourism. 6 (1), 221-232. Available from http://www.chios.aegean. gr/tourism/VOLUME_6_No1_art12.pdf [Accessed 5 ${ }^{\text {th }}$ April 2019]

31. Luković, T. (2007a) Nautički turizam, definiranje i razvrstavanje. Ekonomski pregled: mjesečnik Hrvatskog društva ekonomista Zagreb. 58 (11), 689-708. Available from https://hrcak.srce.hr/ index.php?show $=$ clanak\&id clanak jezik $=28146$ [Accessed $5^{\text {th }}$ April 2019]

32. Luković, T. (2007b) Nautički turizam-definiranje i dileme. Naše more: znanstveni časopis za more i pomorstvo. 54 (1-2), 22-31. Available from https://hrcak.srce.hr/index.php?show=clanak\&id_ clanak_jezik=20164 [Accessed $5^{\text {th }}$ April 2019]

33. Luković, T. (2009) Sukobljene ili sukladne strategije razvoja europskog nautičkog turizma. Pomorstvo: journal of maritime studies. 23 (2), 341-356. Available from https://hrcak.srce. $\mathrm{hr} / 45447$ [Accessed $5^{\text {th }}$ April 2019]

34. Ministry of Sea, Traffic, Infrastructure, and Ministry of Tourism. (2008) Strategy of Development of Nautical Tourism of the Republic of Croatia for the period 2009-2019. Available from http:// www.mppi.hr/UserDocsImages/Strategija\%20razvoja\%20nautickog\%20turizma\%20HR\%201. pdf [Accessed $5^{\text {th }}$ April 2019]

35. Mirakul. (2016) Hrvatska dočekuje ljetnu sezonu kao prepoznata i sigurna destinacija. Available from https://www.mirakul.hr/teme/turizam/hrvatska-docekuje-ljetnu-sezonu-kao-prepoznata-isigurna-destinacija/ [Accessed $5^{\text {th }}$ April 2019]

36. Novotná, M. \& Kunc, J. (2019) Luxury tourists and their preferences: Perspectives in the Czech Republic. Tourism: International Scientific-Professional Journal. 67 (1), 90-95. Available from https://hrcak.srce.hr/index.php?show=clanak\&id_clanak_jezik=318812 [Accessed 5 ${ }^{\text {th }}$ April 2019]

37. Seo, Y. \& Buchanan-Oliver, M. (2015) Luxury branding: the industry, trends, and future conceptualisations. Asia Pacific Journal of Marketing and Logistics. 27 (1), 82-98. Available from https://www.emeraldinsight.com/doi/abs/10.1108/APJML-10-2014-0148 [Accessed $5^{\text {th }}$ April 2019]

38. State Bureau for Statistics. (n.d.) Nautical Tourism Capacities and Business of ports of Nautical Tourism in the period 2014-2018. Available at: www.dzs.hr [accessed 30 $0^{\text {th }}$ March 2019]

39. Thirumaran, J. (2016) Challenges in Emerging Research on Luxury Destinations (Editorial). Journal of Tourism Research and Hospitality. 5 (2), 1-2. Available from https://www.scitechnol. com/peer-review/challenges-in-emerging-research-on-luxury-destinations-1FpR.php?article_ id $=5161$ [Accessed $5^{\text {th }}$ April 2019]

40. UNWTO. (2018) UNWTO Tourism Highlights 2018 Edition. Available from https://www.eunwto.org/doi/pdf/10.18111/9789284419876 [Accessed $5^{\text {th }}$ April 2019]

41. Vitasović, A. \& Dujmović, M. (2017) Experience in Tourist Destination. In: Jiménez Cabellero, J. L., Simonetti, B. \& Squillante, M. (eds.) International Conference on Tourism Dynamics and Trends Proceedings Book II, 26-29 June 2017, Seville, Spain. Seville: Faculty of Tourism and Finance, University of Seville. pp. 76-94

42. Wiedmann, K-P., Hennigs, N. \& Siebls, A. (2009) Value-Based Segmentation of Luxury Consumption Behavior. Psychology \& Marketing. 26 (7), 625-651. Available from https:// onlinelibrary.wiley.com/doi/abs/10.1002/mar.20292 [Accessed $5^{\text {th }}$ April 2019]

43. Youzcu, O.K. (2017) Competitiveness of Istanbul as a Tourism Destination for Luxury Market. Journal of Tourismology. 3 (2), 2-13. Available from http://www.journals.istanbul.edu.tr/ iuturizmoloji/article/view/5000206921/5000183376 [Accessed $5^{\text {th }}$ April 2019] 